\title{
Peningkatan Grade Kain Sarung dengan Mengurangi Cacat Menggunakan Metode Kaizen dan Siklus PDCA pada PT. $X$
}

\author{
Muhammad Saiful Arif ${ }^{1}$, Chauliah Fatma Putri², Ngudi Tjahjono ${ }^{3}$ \\ ${ }^{1}$ Fakultas Teknik, Jurusan Teknik Industri, Universitas Widyagama Malang \\ ${ }^{2}$ Fakultas Teknik, Jurusan Teknik Industri, Universitas Widyagama Malang \\ ${ }^{3}$ Fakultas Teknik, Jurusan Teknik Industri, Universitas Widyagama Malang \\ Email: nguditjahjono@gmail.com
}

\begin{abstract}
Abstrak
Perkembangan industri yang semakin pesat menuntut perusahaan agar dapat bersaing dengan cara meningkatkan kualitas produk. Untuk meningkatkan kualitas produk, perusahaan mengikuti standar kualitas seperti pada PT. X yang merupakan perusahaan textile berorientasi ekspor. Perusahaan ini memiliki standar kualitas internasional yaitu ISO 9001 dan ISO 14001. Permasalahan kemudian muncul ketika perusahaan memiliki banyak cacat produk dan tidak memenuhi standar yang ditentukan. Pada PT. X, kurangnya pengendalian kualitas khususnya pada Grade non-A dimana kain sarung memiliki tingkat defect (kecacatan) yang cukup tinggi sehingga akan merugikan perusahaan. Oleh karena itu, penelitian ini bertujuan untuk memperoleh efisiensi proses kerja yang baik dengan upaya meningkatkan kualitas grade secara efektif, dengan menggunakan konsep Kaizen dan PDCA (Plan, Do, Check, and action). Hasil dari penelitian ini menunjukkan prosentase cacat yang paling besar didominasi oleh Filling bar sebesar 12373 atau 1,25\% pada bulan Desember 2016.
\end{abstract}

Kata kunci: Pengendalian kualitas, kaizen, PDCA, cacat produk.

\begin{abstract}
The rapid growth of industrial competition forces the companies to attain the competitive advantage by improving their product quality. To improve the product quality, the company requires to follows the international or national standards of Quality. For example, PT. X which is an export-oriented textile company should fulfil the standard of ISO 9001 and ISO 14001. However, this company has the issue such as many products are defects and does not meet the quality standard of specification. In PT. X, the high level of defect shows that the quality control is not too good, more specifically for the grade of non- $A$ grade. Therefore, this study aims to obtain the process efficiency by improving the grade quality by using PDCA (Plan, Do, Check, and action). The results of this study show that the largest percentage of defects is dominated by Filling bars of 12373 or 1.25\% in December 2016.
\end{abstract}

Keywords: Quality control, Kaizen, PDCA, product defects. 


\section{PENDAHULUAN}

Perbaikan kualitas merupakan salah satu upaya yang dapat dilakukan perusahaan untuk mencapai keunggulan kompetitif. Hal ini juga dilakukan oleh PT. $\mathrm{X}$ yang merupakan perusahaan textile berorientasi ekspor. Untuk mencapai standar yang telah ditentukan yaitu standar ISO 9001 dan ISO 14001, perusahaan menerapkan pengelompokan grade. Grade adalah pengelompokan barang ke dalam standar kualitas yang diakui. Grade yang baik menjadi hal yang sangat vital dalam suatu produksi textile dan merupakan faktor kunci yang dapat membawa keberhasilan, pertumbuhan, dan peningkatan posisi dalam persaingan. Grade sendiri dibagi 2 yaitu grade A dan grade non-A.

Masalah dihadapi dalam perusahaan textile ini adalah kurangnya pengendalian kualitas khususnya pada Grade non-A dimana kain sarung memiliki tingkat defect (kecacatan) yang cukup tinggi sehingga akan merugikan perusahaan. Pada hasil produksi di PT. X, banyak ditemukan defect (cacat) produk seperti Floating, Bar, Abnormal salvage, Temple mark dan masih banyak lagi yang secara otomatis dapat memengaruhi kualitas produk. Oleh karena itu ketelitian dan control produk sangat perlu dilakukan untuk mengurangi defect (cacat) yang terjadi pada proses produksi. Untuk itu dalam memroduksi suatu produk terutama kain sarung, penting bagi perusahaan untuk menerapkan perencanaan, pengecekan dan action yang tepat ketika terjadi masalah defect. Selain itu, perusahaan menargetkan kualitas produk $99 \%$ grade A sebagai salah satu usaha untuk memenuhi kebutuhan konsumen dan cacat produk yang ditoleransi hanya maksimal $1 \%$ saja. Walaupun pada kenyataannya, kualitas produk di PT. X masih mencapai $97 \%$.

Pada penelitian terdahulu, alat perbaikan kualitas seperti Kaizen, Six Sigma, dan seven tools statistic digunakan untuk memperbaiki kualitas produk [1] \& [2]. Namun, belum ada yang membahas tentang sistem pengendalian kualitas terintegrasi seperti PDCA (Plain, Do, Check, Action) untuk memperbaiki kualitas. Untuk mengatasi permasalahan yang dihadapi oleh PT X., penelitian ini bertujuan untuk memperoleh efisiensi proses kerja yang baik dengan upaya meningkatkan kualitas grade secara efektif, dengan menggunakan PDCA.

\section{STUDI PUSTAKA}

\subsection{Pengertian Produk Cacat}

Menurut [3], produk cacat adalah produk yang dihasilkan dari proses produksi yang tidak memenuhi standar namun secara ekonomis bila diperbaiki lebih menguntungkan dibanding langsung dijual. Dengan kata lain biaya perbaikan terhadap produk cacat masih lebih rendah dari hasil penjualan produk cacat tersebut setelah diperbaiki. Produk cacat dapat disebabkan karena hal-hal sebagai berikut:

1) Produk cacat yang disebabkan oleh sulitnya pengerjaan.

2) Produk cacat yang disebabkan kurangnya pengendalian dalam perusahaan.

\subsection{Pengertian Kualitas Produk}

Kualitas adalah karakteristik dari produk dalam menunjukkan kemampuannya untuk memenuhi kebutuhan-kebutuhan yang telah ditentukan dan bersifat laten [3]. Sedangkan menurut [4], kualitas adalah keunggulan yang dimiliki oleh produk. Kemudian, [5] menjelaskan arti dari kualitas produk adalah "the ability of a product to perform its functions, it includes the product's overall durability, reliability, precision, ease of operation and repair, and other valued attributes" yang artinya kemampuan sebuah produk dalam menjalankan fungsinya, hal itu termasuk keseluruhan 
durabilitas, reliabilitas, ketepatan, kemudahan pengoperasian dan reparasi produk juga atribut produk lainnya. Berdasarkan definisi-definisi diatas, maka dapat disimpulkan bahwa kualitas Produk (Product Quality) adalah kemampuan suatu produk untuk melaksanakan fungsinya meliputi, daya tahan keandalan, ketepatan kemudahan operasi dan perbaikan, serta atribut bernilai lainnya. Kualitas suatu produk dan jasa dapat dianalisa melalui beberapa tahapan proses dengan memperhitungkan nilai suatu produk dan jasa tanpa adanya kekurangan sedikitpun nilai suatu produk dan jasa, dan menghasilkan produk dan jasa sesuai harapan tinggi dari pelanggan.

Untuk mencapai kualitas produk yang diinginkan maka diperlukan suatu standarisasi kualitas. Cara ini dimaksudkan untuk menjaga agar produk yang dihasilkan memenuhi standar yang telah ditetapkan sehingga konsumen tidak akan kehilangan kepercayaan terhadap produk yang bersangkutan. Pemasar yang tidak memperhatikan kualitas produk yang ditawarkan akan menanggung tidak loyalnya konsumen sehingga penjualan produknya pun akan cenderung menurun. Jika pemasar memperhatikan kualitas, bahkan diperkuat dengan periklanan dan harga yang wajar maka konsumen tidak akan berpikir panjang untuk melakukan pembelian terhadap produk [5]. Berdasarkan penjelasan diatas, maka dapat disimpulkan bahwa kualitas produk adalah keseluruhan barang dan jasa yang berkaitan dengan keinginan konsumen yang secara keunggulan, produk sudah layak dijual dan sesuai dengan harapan dari pelanggan. Kualitas produk dibentuk oleh beberapa indikator antara lain kemudahan penggunaan, daya tahan, kejelasan fungsi, keragaman ukuran produk, dan lain-lain [5].

\subsection{Kaizen}

Kaizen adalah suatu filosofi dari Jepang yang memfokuskan diri pada pengembangan dan penyempurnaan secara terus menerus atau berkesinambungan dalam perusahaan bisnis. Kaizen berasal dari Bahasa Jepang yaitu kai artinya perubahan dan zen artinya baik. Di Cina kaizen bernama gaishan di mana gai berarti perubahan/perbaikan dan shan berarti baik/benefit. Jadi Kaizen dapat diartikan sebagai perubahan kepada arah lebih baik. Kaizen adalah kegiatan sehari-hari yang sederhana bertujuan untuk melampaui peningkatan produktifitas, juga merupakan sebuah proses apabila dilakukan dengan benar akan "memanusiawikan" tempat kerja, mengurangi beban kerja yang berlebihan, dan mengajarkan orang untuk melakukan percobaan dalam pekerjaannya dengan menggunakan metode-metode ilmiah dan bagaimana belajar mengenali serta mengurangi pemborosan dalam proses kerjanya.

Kaizen atau perbaikan secara terus menerus selalu beriringan dengan Total Quality Management (TQM). Bahkan sebelum filosofi TQM ini terlaksana atau sebelum sistem mutu dapat dilaksanakan dalam suatu perusahaan maka filosofi ini tidak akan dapat dilaksanakan sehingga perbaikan secara terus menerus (continuous improvement) ini adalah usaha yang melekat pada filosofi TQM itu sendiri. Sehingga Kaizen bisa juga merupakan suatu kesatuan pandangan yang komprehensif dan terintegrasi yang memiliki ciri khas:

1. Berorientasi pada pelanggan.

2. Pengendalian mutu secara menyeluruh (Total Quality Management)

3. Robotik

4. Gugus kendali mutu

5. Sistem saran

6. Otomatisasi

7. Displin ditempat kerja

8. Pemeliharan produktvitas 
9. Penyempurnaan dan perbaikan mutu

10. Tepat waktu

11. Tanpa cacat

12. Kegiatan kelompok kecil

13. Hubungan kerjasama antara manajer dan karyawan

\subsection{PDCA (Plan - Do - Check - Action)}

Deming yang merupakan pencetus dari siklus PDCA ini mengatakan bahwa jika organisasi ingin menghasilkan mutu dari produk atau jasa yang akan dihasilkan, maka roda siklus PDCA harus berputar. Artinya, proses Plan Do Check Action harus dijalankan. Pekerjaan harus direncanakan. Rencana yang telah dibuat harus dijalankan. Pelaksanaan pekerjaan dimonitor, diukur atau dinilai. Hasil penilaian dilakukan analisis, hasil analisis digunakan untuk merencanakan pengembangan berikutnya. Demikian seterusnya sehingga siklus PDCA berjalan dan organisasi akan selalu mampu memenuhi standar mutu dan berkembang secara berkelanjutan.

Siklus PDCA dapat diibaratkan seperti sebuah bola yang harus didorong naik menuju ke arah tujuan yang telah ditetapkan yang letaknya di atas. Untuk itu diperlukan upaya dan tenaga yang tidak sedikit untuk mencapai tujuan tersebut. Untuk implementasi PDCA, diperlukan keterlibatan semua pihak yang berkepentingan. Dalam meningkatkan mutu, diperlukan berbagai upaya agar siklus PDCA dapat terus meningkatkan mutu produk.

\section{METODE}

Metode yang digunakan pada penelitian ini dapat diilustrasikan pada Gambar1.

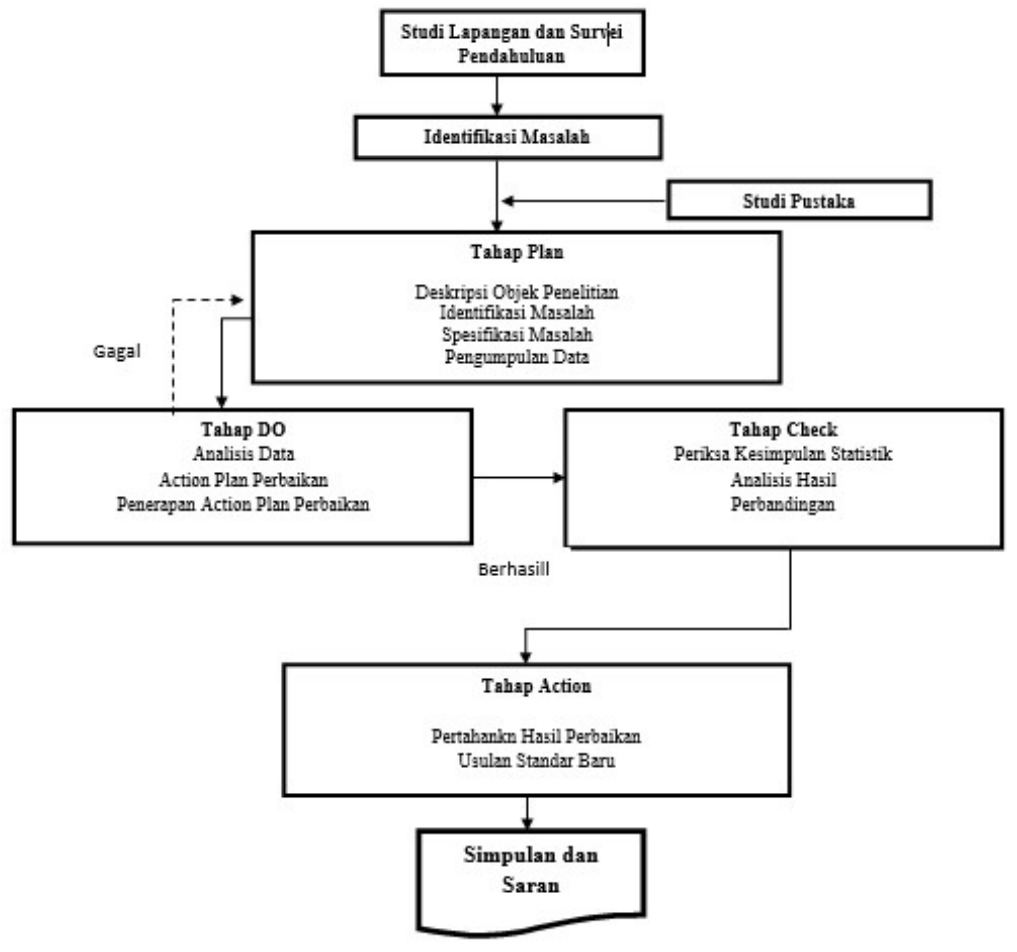

Gambar 1. Metode Penelitian 


\subsection{Studi Lapangan dan Survei Pendahuluan}

Penelitian ini dilakukan pada perusahaan yang bergerak dibidang industri textile. Perusahaan ini memroduksi kain tepatnya yaitu kain sarung tenun modern. Ini adalah tahap pengenalan terhadap lokasi penelitian dari objek penelitian. Penelitian ini dilakukan pada departemen Air Jet Lom (AJL). Departemen AJL ini adalah departemen yang memproduksi kain sarung tersebut. Disini proses produksi dilakukan untuk membuat kain sarung tersebut.

\subsection{Identifikasi Masalah}

Pada tahap ini, identifikasi masalah di PT. X didasarkan atas kondisi di pihak produksi yang terfokus pada besarnya defect atau cacat produk pada pada pembuatan kain sarung. Semakin banyaknya cacat produk selama proses produksi tersebut dikhawatirkan menimbulkan kerugian yang lebih besar bagi perusahaan. Dengan data produksi perusahaan selama 5 bulan sebelumnya yaitu mulai bulan Agustus, September, Oktober, November, dan Desember 2016. PT. X memproduksi kain sarung untuk memenuhi kebutuhan customer. Dalam pembuatan kain sarung ada beberapa item defect atau cacat produk yang sering terjadi yaitu Floating, Filling Bar, Abnormal Salvage, Temple Mark, Pakan belang, Broken Weft dan Broken Warp.

\subsection{Studi Pustaka}

Pada tahap ini dilakukan studi tentang teori-teori yang berguna sebagai acuan dalam menyelesaikan masalah tentang peningkatan grade kain sarung dengan metode Kaizen dan siklus PDCA. Tahap ini dilakukan bertujuan untuk mendapatkan referensi yang dapat mendukung pemecahan masalah yang ada. Sumber pendukung dalam penelitian diambil dari buku-buku, jurnal ilmiah, dan skripsi atau tugas akhir lainnya yang memuat teori-teori yang berkaitan dengan permasalahan tersebut. Studi literatur merupakan penunjang dan sumber ilmu yang digunakan sebagai landasan teori.

\subsection{Pengumpulan Data}

Data yang digunakan dalam penelitian ini yaitu data yang diperoleh dari kuesioner, wawancara, catatan pengamatan, dan dokumentasi. Analisis ini digunakan untuk mengetahui cara mengurangi cacat produk untuk meningkatkan grade kain sarung.

\subsection{Pengolahan Data}

Data yang dikumpulkan kemudian diolah agar dapat digunakan dalam penelitian. Tujuan pengolahan data adalah untuk mengolah data yang telah diperoleh dan melakukan uji validasi dan verifikasi data. Adapun tahap pengolahan data yang di lakukan dalam penelitian ini adalah Siklus PDCA atau Plan-Do-Check - Action.

\section{HASIL DAN PEMBAHASAN}

\subsection{Identifikasi Masalah}

Teknik yang dilakukan dalam spesifikasi masalah bertujuan untuk mencari cacat produk yang dominan yang menyebabkan grade atau kualitas produksi kain sarung di PT. X meningkat. Pengumpulan data dilakukan dengan cara pengambilan 
data (record) dari data laporan kualitas produksi bulanan PT. X. Tabel 1 . menunjukkan data tentang defect atau cacat produk yang terjadi pada departemen weaving atau tempat produksi kain sarung.

Dari tabel 1, dapat diketahui dan diidentifikasi jumlah cacat yang terjadi di dalam proses produksi, terdapat dua jenis cacat yang melebihi dari standart yang ditentukan yaitu 1\% Grade non-A yaitu Filling bar dan Abnormal salvage. Cacat Filling bar terbesar mencapai 12373 pieces $(1,25 \%)$ dari total produksi pada bulan Desember 2016 dan cacat Abormal salvage mencapai 10840 pieces $(1,10 \%)$ dari total produksi pada bulan Desember 2016.

Tabel 1. Cacat produk Grade A bulan Agustus - Desember 2016

\begin{tabular}{|c|c|c|c|c|c|c|c|c|}
\hline \multirow[b]{2}{*}{ Bulan } & \multirow[b]{2}{*}{$\begin{array}{c}\text { Total } \\
\text { Produksi }\end{array}$} & \multicolumn{7}{|c|}{ Rata - rata jumlah cacat } \\
\hline & & $\begin{array}{c}\text { Floating } \\
(\%)\end{array}$ & $\begin{array}{l}\text { Filling } \\
\text { Bar (\%) }\end{array}$ & $\begin{array}{c}\text { Abnormal } \\
\text { Salvage } \\
\text { (\%) }\end{array}$ & $\begin{array}{c}\text { Temple } \\
\text { Mark } \\
(\%)\end{array}$ & $\begin{array}{c}\text { Pakan } \\
\text { Belang } \\
(\%)\end{array}$ & $\begin{array}{c}\text { Broken } \\
\text { Weft } \\
(\%)\end{array}$ & $\begin{array}{c}\text { Broken } \\
\text { Warp } \\
(\%)\end{array}$ \\
\hline Agustus & 744212 & $\begin{array}{c}528 \\
(0,07)\end{array}$ & $\begin{array}{c}8622 \\
(1,16)\end{array}$ & $\begin{array}{c}6294 \\
(0,85)\end{array}$ & $\begin{array}{c}56 \\
(0,01)\end{array}$ & $\begin{array}{c}142 \\
(0,02)\end{array}$ & $\begin{array}{c}408 \\
(0,05)\end{array}$ & $\begin{array}{c}411 \\
(0,06)\end{array}$ \\
\hline September & 805372 & $\begin{array}{c}450 \\
(0,06)\end{array}$ & $\begin{array}{c}9225 \\
(1,15)\end{array}$ & $\begin{array}{c}8575 \\
(1,06)\end{array}$ & $\begin{array}{c}67 \\
(0,01)\end{array}$ & $\begin{array}{c}356 \\
(0,04)\end{array}$ & $\begin{array}{c}504 \\
(0,06)\end{array}$ & $\begin{array}{c}411 \\
(0.05)\end{array}$ \\
\hline Oktober & 885438 & $\begin{array}{c}511 \\
(0,06)\end{array}$ & $\begin{array}{l}10681 \\
(1,20)\end{array}$ & $\begin{array}{c}9825 \\
(1,02)\end{array}$ & $\begin{array}{c}191 \\
(0,02)\end{array}$ & $\begin{array}{c}391 \\
(0,04)\end{array}$ & $\begin{array}{c}734 \\
(0,08)\end{array}$ & $\begin{array}{l}1367 \\
(0,15)\end{array}$ \\
\hline Nopember & 920305 & $\begin{array}{c}524 \\
(0,06)\end{array}$ & $\begin{array}{l}11436 \\
(1,24)\end{array}$ & $\begin{array}{c}9425 \\
(1,02)\end{array}$ & $\begin{array}{c}149 \\
(0,02)\end{array}$ & $\begin{array}{c}446 \\
(0,05)\end{array}$ & $\begin{array}{c}931 \\
(0,10)\end{array}$ & $\begin{array}{c}1260 \\
(0,14)\end{array}$ \\
\hline Desember & 987250 & $\begin{array}{c}401 \\
(0,04)\end{array}$ & $\begin{array}{l}12373 \\
(1,25)\end{array}$ & $\begin{array}{l}10840 \\
(1,10)\end{array}$ & $\begin{array}{c}79 \\
(0,01)\end{array}$ & $\begin{array}{c}565 \\
(0,06)\end{array}$ & $\begin{array}{c}866 \\
(0,09)\end{array}$ & $\begin{array}{c}1692 \\
(0,17)\end{array}$ \\
\hline Jumlah & 4342577 & $\begin{array}{l}2414 \\
(0,06) \\
\end{array}$ & $\begin{array}{l}52337 \\
(1,21) \\
\end{array}$ & $\begin{array}{l}44959 \\
(1,04) \\
\end{array}$ & $\begin{array}{c}542 \\
(0,01)\end{array}$ & $\begin{array}{l}1900 \\
(0,04) \\
\end{array}$ & $\begin{array}{l}3443 \\
(0,08)\end{array}$ & $\begin{array}{l}5141 \\
(0,12)\end{array}$ \\
\hline Rata - rata & 868515,4 & 482,8 & 10467,4 & 8991,8 & 108,4 & 380 & 688,6 & 943.5 \\
\hline
\end{tabular}

Kemudian Tabel 2 menggambarkan efisiensi kerja yang dicapai pada bulan Agustus sampai Desember diperoleh dari data bagian produksi PT. X.

Tabel 2 Efisiensi kerja mesin bulan Agustus sampai Desember

\begin{tabular}{|l|l|l|}
\hline No & \multicolumn{1}{|c|}{ Bulan } & Efisiensi kerja (\%) \\
\hline 1 & Agustus & $75.36 \%$ \\
\hline 2 & September & $76.02 \%$ \\
\hline 3 & Oktober & $73.82 \%$ \\
\hline 4 & November & $78.55 \%$ \\
\hline 5 & Desember & $77.96 \%$ \\
\hline
\end{tabular}

Dari tabel di atas diketahui dan diidentifikasi bahwa efisiensi kerja tertinggi yaitu 78,55\% pada bulan November 2016 dan efisiensi kerja terendah yaitu 75,36\% pada bulan Agustus 2016.

\subsection{Pengumpulan Data}

Pengumpulan data bertujuan untuk mengetahui secara kuantitatif beberapa penyebab yang dapat menimbulkan masalah. Langkah awal pengumpulan data dilakukan dengan mengamati proses produksi terpilih yaitu Departemen weaving Air Jet Loom atau tempat membuat kain sarung dilakukan. Dari hasil identifikasi awal, dapat disimpulkan penyebab cacat produk dalam pembuatan kain sarung yaitu:

1. Kurang Kepedulian.

2. Pekerja Lelah.

3. Beban Kerja Terlalu Banyak/Multi job.

4. Tuck in Abnormal.

5. Benang Leno Putus. 
6. Tekanan Udara Tidak Normal.

7. Catcord tidak standar.

8. Mesin Rusak.

9. Benang Pakan Jelek.

10. Benang Lusi Tidak Ada Kanji.

11. Suhu Udara Panas.

\subsection{Tahap Do}

Teknik analisis data menerapkan salah satu dari tujuh alat bantu (seven tools). Salah satu alat bantu yang digunakan dalam analisis data pada pembahasan ini adalah diagram pareto. Diagram Pareto adalah grafik batang yang menunjukkan masalah berdasarkan urutan banyaknya kejadian (Kwalasetia 2002).

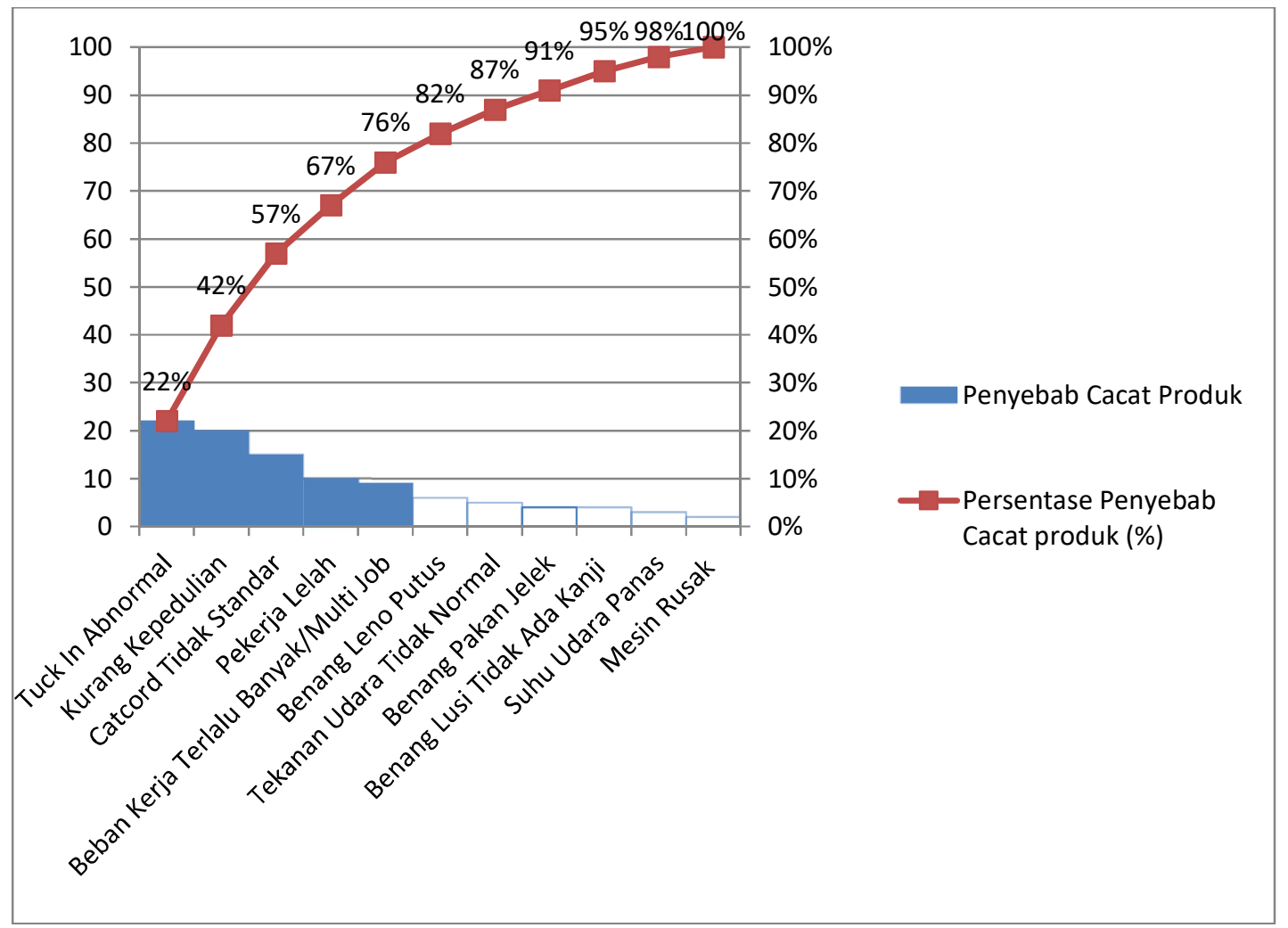

Gambar 2 Diagram pareto frekuensi kejadian faktor penyebab cacat produk pada PT.X

Berdasarkan interprestasi dari diagram pareto yang ditunjukkan Gambar 2, terdapat lima faktor paling dominan yang dilihat dari prosentase penyebab cacatnya melebihi $70 \%$. Kemudian dibuat diagram tulang ikan untuk mengetahui penyebabpenyebab cacat tersebut yang diilustrasikan pada Gambar 3. 


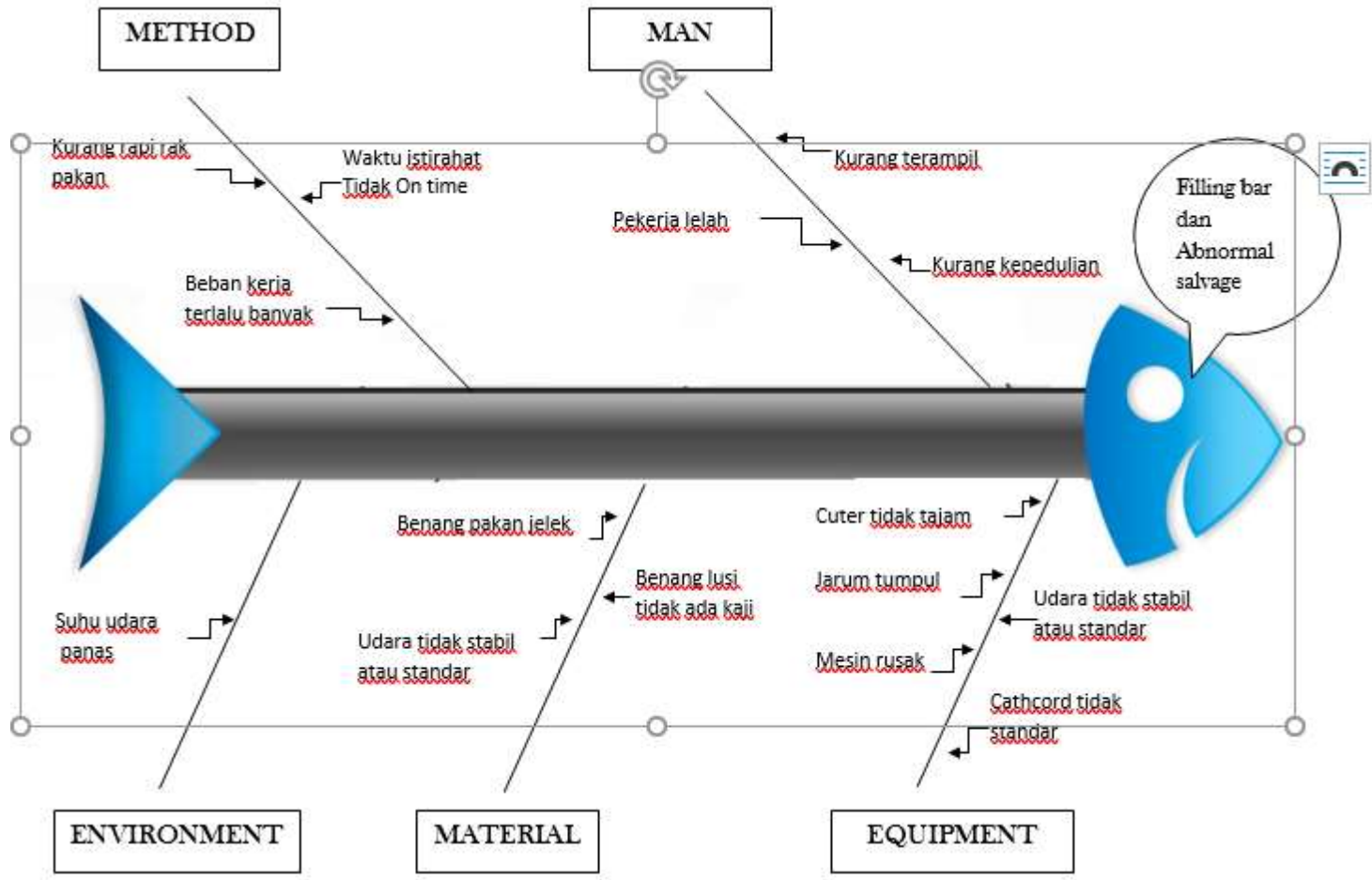

Gambar 3 Diagram tulang ikan penyebab cacat produk pada PT.X

Alternatif perbaikan yang dilakukan untuk menangani permasalahan yang ada disusun dalam suatu rencana kerja (action plan). Action plan dibuat dengan melihat penyebab munculnya masalah dan juga mengunakan metode Kaizen untuk penanganan masalahnya. Action plan akan diterapkan secara continuous improvement dapat dilihat pada Tabel 3.

Tabel 3. Action Plan Perbaikan

\begin{tabular}{|c|c|c|c|}
\hline No & Permasalahan & Penyebab & Perbaikan \\
\hline 1 & Tuck in Abnormal & $\begin{array}{l}\text { Lobang udara griper } \\
\text { tertutup kotoran. } \\
\text { - Jarum tuck in patah. } \\
\text { - Jarum tuck in tidak } \\
\text { standart. } \\
\text { - Cutter tuckin kocak. } \\
\text { - Timming atau drajat tuck } \\
\text { in tidak standart. }\end{array}$ & $\begin{array}{l}\text { - Selalu melakukan } \\
\text { pengontrolan pada tuck in } \\
\text { apakah ada masalah atau } \\
\text { tidak. } \\
\text { - Selalu menjaga griper dan } \\
\text { cutter selalu bersih. }\end{array}$ \\
\hline 2 & Kurang kepedulian & $\begin{array}{ll}\text { - } & \text { Mengabaikan SOP di } \\
\text { dalam sektor } \\
\text { produksi. } \\
\text { - } \\
\text { Mengabaikan cacat } \\
\text { produk kecil. } \\
\text { Tidak adanya } \\
\text { perbaikan yang } \\
\text { dilakukan. } \\
\text { Mengabaikan benang } \\
\text { lusi silang (crossing). }\end{array}$ & $\begin{array}{l}\text { Menerapkan 5S Kaizen } \\
\text { yaitu Seiri atau } \\
\text { pemilihan, Seiton atau } \\
\text { penataan, Seiso atau } \\
\text { Pembersihan, Seiketsu } \\
\text { atau pemantapan, } \\
\text { Shitsuke atau } \\
\text { pembiasaan. } \\
\text { Membiasakan diri } \\
\text { meluruskan benang } \\
\text { yang silang (crossing). }\end{array}$ \\
\hline
\end{tabular}


Tabel 3. Action Plan Perbaikan (lanjutan)

\begin{tabular}{|c|c|c|c|}
\hline No & Permasalahan & Penyebab & Perbaikan \\
\hline 3 & $\begin{array}{l}\text { Catcord Tidak } \\
\text { Standar }\end{array}$ & 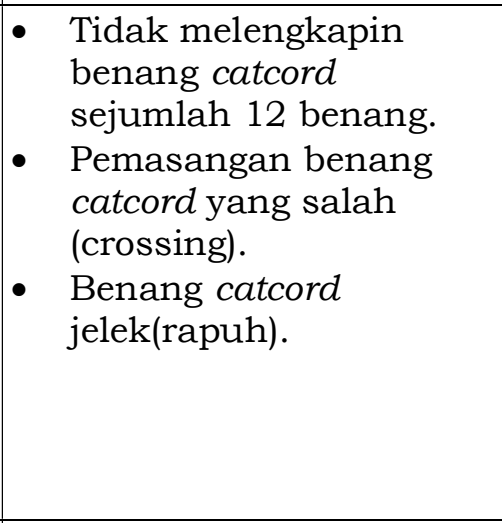 & $\begin{array}{l}\text { - Selalu mengontrol } \\
\text { catcord apakah sudah } \\
\text { lengkap } 12 \text { benang } \\
\text { atau belum. } \\
\text { - Selalu mengontrol } \\
\text { pemasangan benang } \\
\text { catcord tidak silang. } \\
\text { Melakukan } \\
\text { penggantian benang } \\
\text { catcord yang jelek atau } \\
\text { yang rapuh dengan } \\
\text { yang baik. }\end{array}$ \\
\hline 4 & Pekerja Lelah & $\begin{array}{ll}\text { - } & \text { Kurangnya waktu } \\
\text { istirhat } \\
\text { - } \\
\text { Terlalu banyak aktivitas } \\
\text { diluar jam kerja }\end{array}$ & $\begin{array}{ll}\text { - } & \text { Melakukan } \\
\text { pembatasan aktivitas } \\
\text { - } \\
\text { Mengatur jam istirahat } \\
\text { 5-8 jam }\end{array}$ \\
\hline 5 & $\begin{array}{l}\text { Beban Kerja } \\
\text { Terlalu } \\
\text { Banyak/Multi Job }\end{array}$ & $\begin{array}{l}\text { Kurangnya pembiasaan } \\
\text { diri terhadap } \\
\text { pekerjaanya }\end{array}$ & $\begin{array}{l}\text { - Senantiasa } \\
\text { menerapkan } 5 \mathrm{~s} \text { dalam } \\
\text { Kaizen } \\
\text { - Selalu semangat dalam } \\
\text { bekerja }\end{array}$ \\
\hline
\end{tabular}

Hasil pengamatan dari faktor penyebab cacat kain sarung pada PT. X selama 5 bulan proses produksi dapat dilihat pada histogram berikut ini:

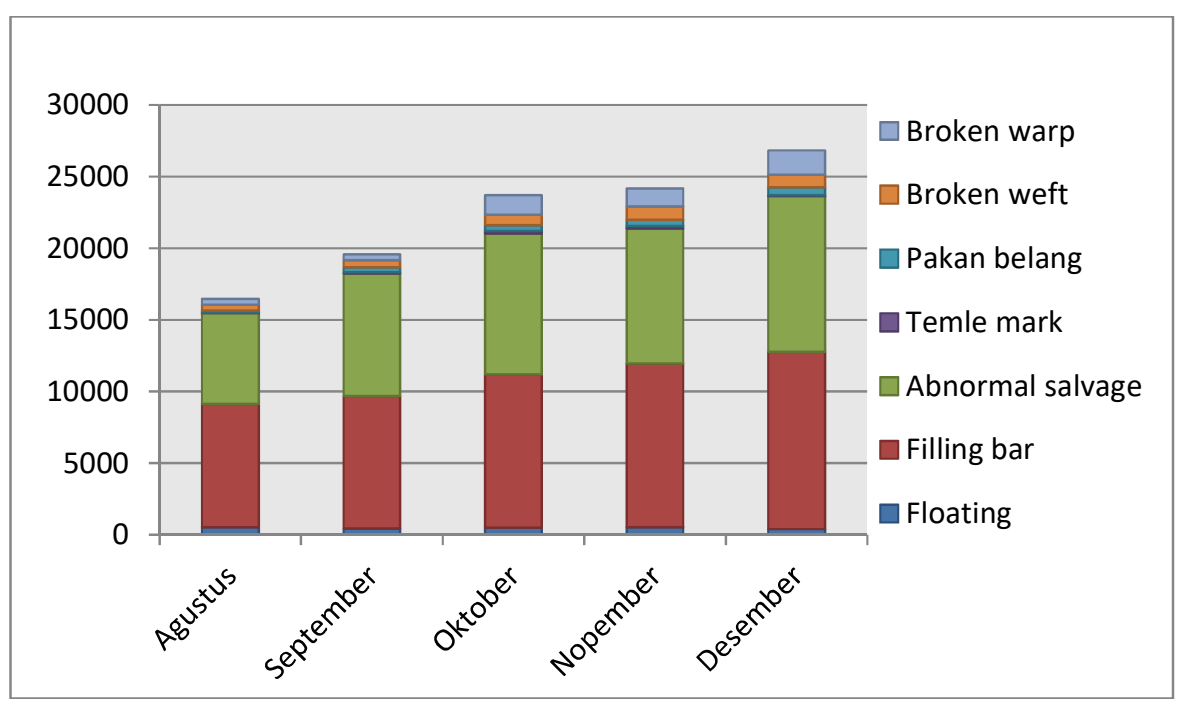

Gambar 4. Histogram Jenis-jenis dan Banyaknya Produk Cacat Kain Sarung di PT. $X$

\section{KESIMPULAN}

Berdasarkan pengumpulan dan pengolahan data menggunakan metode Kaizen dan Siklus PDCA, maka dapat disimpulkan bahwa prosentase cacat yang paling besar didominasi oleh Filling bar sebesar 12373 atau 1,25\% pada bulan Desember 2016. Berikutnya prosentase cacat terbesar diikuti oleh Abormal salvage sebesar 10840 pieces $(1,10 \%)$ pada bulan Desember 2016. Kemudian, upaya untuk 
menaikkan efisiensi dengan perbaikan dan pengontrolan kelima faktor penyebab cacat yaitu Tuckin abnormal, Kurang kepedulian, Catcord tidak standart, Pekerja lelah, dan Beban kerja terlalu banyak. Penerapan rencana kerja (Action Plan), Perbaikan yang telah dibuat dengan melihat penyebab munculnya masalah dan juga menggunakan metode Kaizen untuk penanganannya. Dengan menerapkan metode Kaizen dan siklus PDCA secara Continuous improvement diperoleh peningkatan Grade dan efisiensi kerja. Peningkatan Grade dengan penurunan cacat Filling sebesar 14160 pieces $(0,40 \%)$ dan cacat Abnormal salvage sebesar 4504 pieces $(0,13 \%)$ dan peningkatan efisiensi kerja yang semula rata- rata $76 \%$ menjadi $82,62 \%$ setelah perbaikan.

Penelitian ini merekomendasikan pemberian benang pakan atau bahan baku benang pakan hendaknya di pilih dengan bahan yang bagus serta pewarnaan yang bagus untuk mengurangi banyaknya pakan belang yang terjadi pada bagian produksi. Selanjutnya perusahaan sebaiknya lebih memperhatikan pekerja dan meningkatkan pengendalian kualitas produk agar cacat produk seminimal mungkin bisa terjadi.

\section{DAFTAR RUJUKAN}

[1] C. I. Parwati dan R. M. Sakti. 2012. "Pengendalian Kualitas Produk Cacat Denga Pendekatan Kaizen Dan Analisis Masalah Dengan Seven Tools." SNAST.Yogyakarta

[2] A. N. Fauzi. 2015. "AnalisisPengendalian Kualitas Produksi Sarung Tangan Di PT.Adi Satria Abadi Dengan menggunakan Metode Six Sigma-DMAIC." UINSK. Yogyakarta.

[3] P. Kotler. 2000. "Manajemen Pemasaran." Edisi Millenium. Jakarta: PT. Prenhallindo.

[4] B. Ayu, 2015. "Makalah Manajemen Mutu Perbaikan Berkesinambungan (Kaizen). Dilihat 08 April 2017. http://bidariayu92.blogspot.co.id/2015/01/ makalah-manajemen-mutu-perbaikan.html

[5] P. Kotler dan A. Gary. 2001. "Prinsip-prinsip Pemasaran." Jakarta: Erlangga. 